専門医症例報告

\title{
複数の主訴に対して補経装置の設計を考慮し改善を困った一症例
}

\author{
堤 一輝
}

A case report of a prosthetics design that accommodated improvements for multiple chief complaints

Ikki Tsutsumi

\begin{abstract}
抄 録
症例の概要：59 歳の女性。咀嚼時の義歯動摇による咀嚼困難，上㠝義歯前歯舌側部に舌が触れることによる違和感， 維持装置・人工歯による審美不良を主訴に来院。欠損部の一部にブリッジを選択し，上下顎部分床義歯を製作した. 考察：前歯部欠損部に対しブリッジを選択したことで審美・感覚障害を, 義歯における大連結子の設計により感覚 障害を改善できたと考える。また，大連結子は口蓋前・後方を被覆しない形態のため，支台装置にミリングテクニッ クを用い義歯の安定性は向上し咀嚼障害を改善できたと考える。

結論 : 各々の障害の要因に対する解決策として補綴装置の設計を考慮し，その要因を取り除いたことで良好な結果 が得られた。

キーワード

補綴装置の設計，大連結子，ミリングテクニック
\end{abstract}

\begin{abstract}
Patient: The patient was a 59-year-old woman examined at our department with chief complaints of masticatory dysfunction due to denture mobility during chewing, unpleasant sensation due to tongue contact with the anterior lingual surface of the upper denture, and esthetic issues due to retainers/artificial teeth. A fixed partial denture in part of the edentulous area and maxilla-mandibular removable partial dentures were fabricated.

Discussion: It is suggested that the selection of the fixed partial denture in the anterior edentulous area and the design of the major connector in the denture improved the esthetic/sensory disturbances, and sensory disturbances, respectively. In addition, because the major connector is shaped so as to leave the anteroposterior palatal region uncovered, it is considered that using the milling technique for the retainers improved denture stability and masticatory disturbances. Conclusion: Favorable results were obtained by carefully considering the design of prostheses and eliminating the causes of disturbances.
\end{abstract}

Key words:

Prosthetics design, Major connector, Milling technique

\author{
I. 緒言 \\ II. 症例の概要 \\ 補綴治療において補綴装置の選択を含めた設計は幾通り \\ も存在する。本症例ではそれぞれ関連し合う複数の障害の \\ 要因を把握し, 多軸により補経装置の設計を考慮 ${ }^{1)}$ する \\ ことでこれらを取り除き良好な結果が得られたので報告す \\ る.

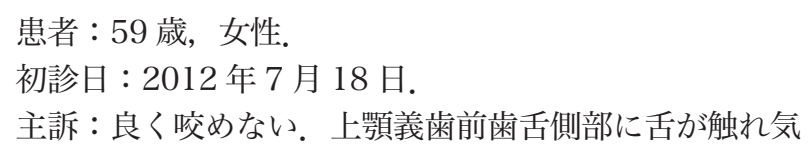

神奈川歯科大学大学院全身管理医歯学講座顎咬合機能回復補経医学分野

Department of Critical Care Medicine and Dentistry, Division of Prosthodontic dentistry for function of TMJ and Occlusion, Graduate School of Dentistry, Kanagawa Dental University

受付 : 2018 年 4 月 29 日 /受理 : 2019 年 6 月 12 日

Received on April 29, 2018/Accepted on June 12, 2019 


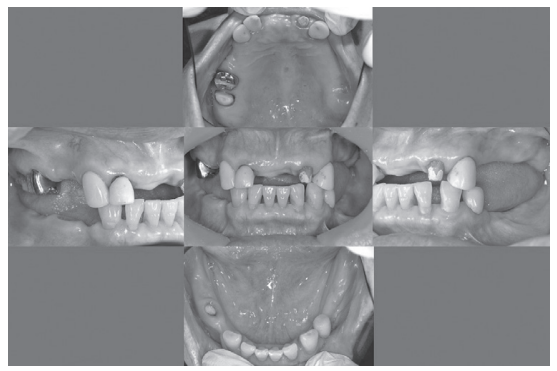

図 1 Intraoral views at the first visit (without denture) 初診時の口腔内写真 (義歯非装着時)

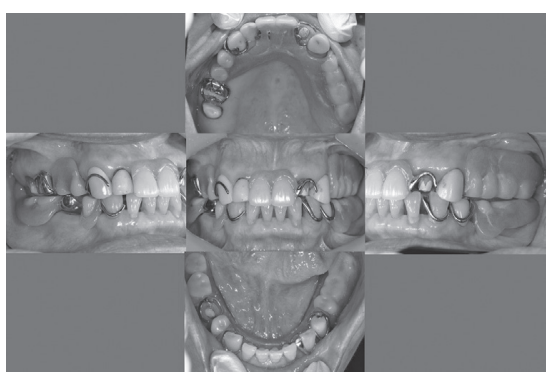

図 2 Intraoral views at the first visit (with denture) 初診時の口腔内写真（義歯装着時）

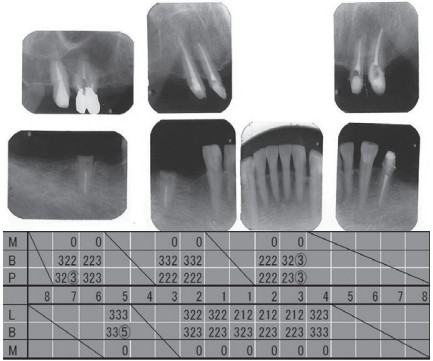

図 3 Dental radiographs and periodontal condition at the first examination 初診時のデンタルエックス線写真およ び歯周組織検査
既往歴：関節リウマチ.

現病歴： 4 年程前に他院にて $\underline{1 \mid 1}$ 歯冠補綴装置を二次力 リエスにて抜歯後，義歯を製作したが上頢義歯は違和感が 大きく何度も調整を行い，義歯後縁の削合により口蓋後方 部の違和感は無くなったが，上顎義歯前歯舌側部に舌が触 れることにより起こる違和感は消失しなかった。この違和 感，疼痛，咀嚼困難，審美不良，および上顎義歯前歯部の 破折が頻繁に起こることを主訴に 2 年程前に別の歯科医 院を受診し，以降複数の歯科医院を受診した。そして最後 に受診した歯科医院で，この問題に対しては上顎に磁性ア タッチメントを用いたオーバーデンチャーにするしかない と言われ根管治療終了後, 磁性アタッチメントを用いた義 歯および，磁性アタッチメント用キーパー付根面板の模型 を見せられた。しかし義歯非装着時の見た目が受け入れら れず，自分の歯で咬みたいと思い，当科を受診した。

現症 : 初診時の義歯非装着時, および装着時の口腔内写

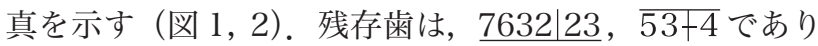
Eichiner の分類は B4，宮地の咬合三角 ${ }^{2)}$ による分類は第 IIIエリアであった。

7632|23，5|4 は根管治療がなされ， 632|3， 4 に暫間 被覆冠が装着されていた。 5 は残根状態であり近心に破 折線を認めた。

上下顎欠損部に対して部分床義歯を装着しており，上顎 義歯は口蓋部の床が削合され， $1 \mid 1$ 舌側部には破折による 修理がなされていた。上下顎義歯において人工歯は咬耗が 確認され咬合面再形成がなされていたが咬合接触状態は不 良であった。

さらに患者は上下顎審美領域のクラスプおよび $1 \mid 1$ 人工 歯部に対して審美不良と， $1 \mid 1$ 舌側部の床に舌尖が触れる ことによる違和感を訴えていた。

検査結果：デンタルエックス線写真，歯周組織検査の結 果を図 3 に示す。デンタルエックス線写真にて全顎的に軽 度の水平的骨吸収が認められた。歯周組織検査にて 5 に $5 \mathrm{~mm}$ の歯周ポケットを認め，他は $3 \mathrm{~mm}$ 以内であり動 摇は全歯において認められなかった。シリコーン印象材を 用いた咬合接触状態の検査 (バイトアイ, GC, 東京, 日本) では咬合接触面積 $8\left(\mathrm{~mm}^{2}\right)$, 咬合接触数 25 (number),
バランス評価は RANK E であり, 佐藤らの咀嚼機能評価 表 ${ }^{3)}$ による咀嚼スコアは 35 (点) であった。義歯装着時 の安静空隙量は約 $4 \mathrm{~mm}$ であり, 顔面計測法からも咬合 高径の低下が疑われた。

診断：上顎部分床義歯の不備による咀嚼障害・感覚障害・ 審美障害，下顎部分床義歯の不備による咀嚼障害・審美障 害，5歯根破折による疼痛 (予測).

日本補経歯科学会の部分歯列欠損についての症型分類 ${ }^{4)}$ では難易度判定は Level IV.

\section{III． 治療内容と経過}

\section{1、治療方針および計画}

患者はインプラントを用いた治療を希望せず，欠損部に 対してはブリッジおよび義歯を用いることとした。また咬 合高径の低下が認められインフォームドコンセントにより 咬合拳上に同意は得られたが治療用義歯の製作には同意が 得られず現在の義歯を治療用義歯として用い咬合拳上を行 うこととした。

1）上顎義歯前歯部舌側の床に舌尖が触れることにより発 現している感覚障害, 2) 審美領域において $1 \mid 1$ のみが義歯 による人工歯であること，および $1 \mid 1$ 欠損部に対して直接 支台装置が側切歯に設計されることによる審美障害, 3）繰 り返し起こっていた $1 \mid 1$ 舌側部の義歯の破折，以上 3 つの 問題点への対策として $1 \mid 1$ 欠損部に対して(3)(2)1|1(2)(3)ブ リッジによる補綴治療を選択することとした。

また上下顎臼歯欠損部に対しては部分床義歯を装着する こととした。

上顎旧義歯は，床後縁の感覚障害 ${ }^{5}$ により義歯床が大き く削合され, 義歯の安定が損なわ机咀嚼障害を呈していた。 そのため上顎義歯製作にあたっては最終補綴装置の大連結 子と同程度の厚み・幅を再現した装置を試適することで, 大連結子を可及的に広く，且つ感覚障害の発現しない範囲 に決定し設定することとした。しかしながらこの感覚障害 への対策により大連結子による充分な支持・把持機能は期 待できないため，鉤歯に対してより多くの支持を求め，ま たミリングテクニックを用い，把持機能を高めることで義 歯の安定性を向上させ，咀嚼障害の改善を図る設計とする 


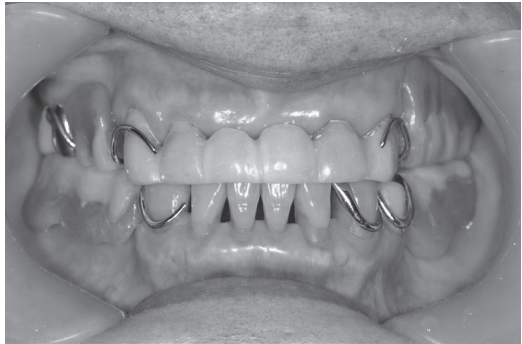

図 4 Intraoral view with temporally bridge and treatment denture (after vertical dimension increased) 暫間被覆冠および治療用義歯装着 時の口腔内写真（咬合拳上後）

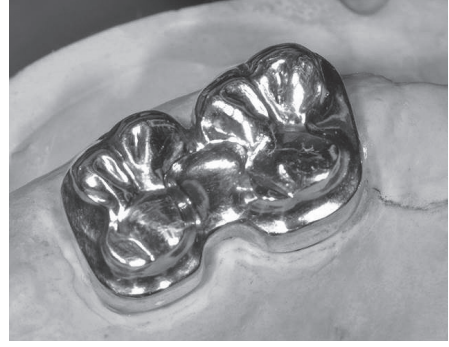

図 5 Crown restoration using the milling technique ミリングテクニックを用いた 歯冠補綴装置

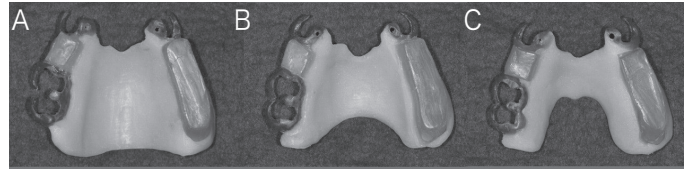

図 6 The devices which reproduced various combinations of thickness, width at the same level as a major connector with tray resin 大連結子と同程度の厚み・幅をトレーレジンにて 再現した装置
こととした ${ }^{6-8)}$.

また上下顎義歯のクラスプは審美領域においては審美障 害への対策として I バークラスプを選択することとした。

\section{2. 処置内容}

破折線の確認された 5 を抜歯，残存歯に対して歯周治 療後， $1 \mid 1$ 欠損部に対して (3)(2)1|1(2)(3)暫間被覆冠を装着, 下顎義歯臼歯部人工歯咬合面に即時重合レジン（ユニファ スト II，GC，東京，日本）を添加し臼歯部で約 $1.5 \mathrm{~mm}$ の咬合拳上を行い治療用義歯として用いた（図 4).2 力月 間使用し咬合拳上による問題が発現しないことを確認後, 7632|23， 4 の支台築造を行い 76|， (3)(2)1|1(2)(3)， 4 に 対してプロビジョナルレストレーションを装着した。調整 を繰り返し 2 力月後76|，(3)(2)1|1(2)(3)，「4に対して付加 型シリコーンゴム印象材（エクザファインパテタイプ・レ ギュラータイプ，GC，東京，日本）にて精密印象，ゴシッ クアーチ描記法を用いた咬合採得を行い, 76」, 4 全部鋳造 冠，(3)12)1 12)3硬質レジン前装冠ブリッジを完成させた.

上顎義歯の鉤歯となる 76 は連結固定を行い， 6 の近 心・舌側面， 7 の遠心・舌側面にミリングテクニックを用 い，各々に近遠心レストシートおよびラベットを付与した (図 5). また $3 \mid 3$ には遠心・舌側面にミリングテクニックを 用い, シンギュラムレストシートを付与した。患者は審美 的要望が強く (3)(2)1|12)(3)ブリッジ製作にあたつては唇側 面および切縁の形態はプロビジョナルレストレーションを 参考にし，またメタルフレーム上の前装部に即時重合レジ ンを添加し試適および調整を行った，機能面において舌面 形態はプロビジョナルレストレーションで調整を行った形 態をクロスマウント法を用いて最終補綴装置へ反映した。

義歯製作には上顎歯冠補経装置にミリングテクニックを 用いたため，完成した歯冠補綴装置を口腔内にて仮着を 行った上で個人トレーを用い筋圧形成，付加型シリコー ン印象材（エクザファインインジェクションタイプ， GC, 東京，日本）にてピックアップ印象を行った。咬合採得は ゴシックアーチ描記法を行いプロビジョナルレストレー ションおよび治療用義歯にて安定の得られた下顎位での採 得を行った ${ }^{9)}$.

上顎義歯の人工歯排列に先立ち，上顎旧義歯にて発現し
ていた感覚障害への対策として，常温重合レジン（松風ト レーレジン，松風，京都，日本）にて前後的幅径・厚みを 最終補綴装置であるコバルトクロム金属床義歯の大連結子 と同程度にした 3 種類の装置を製作し試適・調整を行った. この際，製作した 3 種類の装置は，正中における前後的 幅径・厚みをそれぞれ $35 \mathrm{~mm} \cdot 0.8 \mathrm{~mm}, 22 \mathrm{~mm} \cdot 1.0 \mathrm{~mm}$, $18 \mathrm{~mm} \cdot 1.2 \mathrm{~mm}$ とした（図 $6, \mathrm{~A}, \mathrm{~B}, \mathrm{C}$ )。これにより可 及的に広く, 且つ上顎後縁の感覚障害 - 前歯舌側部の床に 舌尖が触れることによる感覚障害が発現しない大連結子の 形態を決定した（図 6,C）。

人工歯排列試適，メタルフレーム試適を行い，上下顎部 分床義歯を完成させ，歯冠補綴装置および上下顎部分床義 歯を同時に装着した (図 7)。また咬合様式は犬歯誘導とし た.

上顎義歯は鉤歯に付与したミリング面に対し，各々適 合させた小連結子で被覆した。また， $3 \mid 3$ にシンギュラム レスト，Iバークラスプを用い，76溒心にレスト， 煩側に維持腕を用いた。

下顎義歯は 3 にシンギュラムレスト， I バークラスプ, $\sqrt{4}$ にRPI クラスプを用いた。 大連結子は歯周組織および プラークコントロールが良好であったため，支持・把持機 能の向上を目的とし下顎舌側基底結節部を被覆したリンガ ルエプロンを検討した。しかしながら下顎前歯部の下部鼓 形空隙が大きく同部を被覆することによる審美性の低下を 考慮し, 上縁は歯肉辺縁を解放し可能な範囲で幅を広くし たリンガルプレートとした。

\section{3. 術後の経過}

補経治療終了後，3 力月に一度の粘膜面の適合検査およ び咬合接触状態の確認，メインテナンスを行っているが， パノラマエックス線写真, 歯周組織検査からも大きな変化 はなく経過は良好である(図 8,9).

佐藤らの満足度評価 $(\mathrm{VAS})^{10)}$ の平均值は，術前が $25 \%$ であったのに対し補綴治療終了時は 100\%であった。術 後 33 力月時に硬質レジン前装冠に若干の変色を認めたも のの術後 36 力月時における満足度評価の平均值は $98 \%$ と高い值を維持している（表 1$)$.

また残存歯による臼歯部の咬合支持がないため残存歯お 


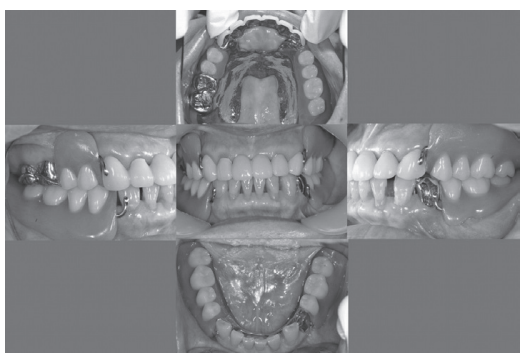

図 7 Intraoral views after prosthetic treatment 補綴治療終了時の口腔内写真

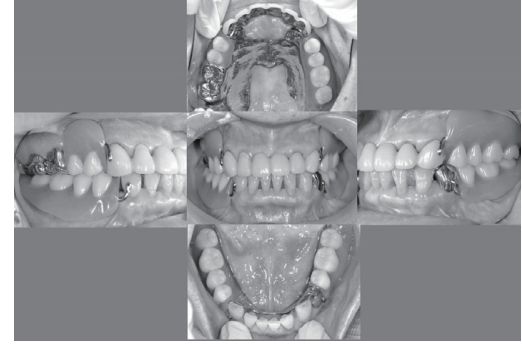

図 8 Intraoral views at 3.5 years after prosthetic treatment 補綴治療終了後 3 年 6 力月時の口腔内写真

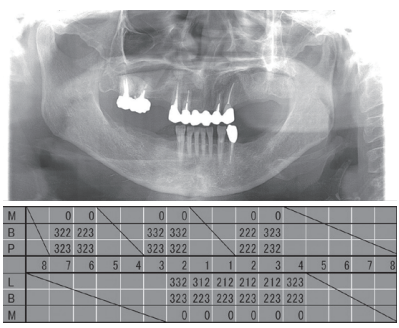

図 9 Panoramic radiography and periodontal condition at 3.5 years after prosthetic treatment 補綴治療終了 3 年 6 力月時のパノラマ エックス線写真および歯周組織検査

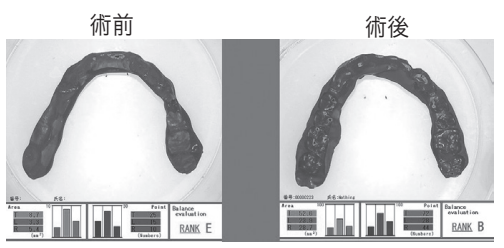

図 10 Evaluation of occlusal conditions by Bite-eye before and after treatment

バイトアイによる術前・術後の咬合状態評価

表 1 Transition of evaluation of the satisfaction of removable partial denture using visual analogue scale (VAS) 義歯に対する満足度評価の推移 (VAS)

\begin{tabular}{cccccc}
\hline 治療前 & 治療中 & 治療後 & 12 力月後 & 24 力月後 & 36 力月後 \\
\hline $25 \%$ & $79 \%$ & $100 \%$ & $98 \%$ & $98 \%$ & $98 \%$ \\
\hline
\end{tabular}

よび㖽関節の過剩負荷を防止する目的で夜間の義歯使用を 指導しているが，義歯の清掃状態も良好である。

\section{4. 術後の機能評価}

補経治療終了後, 咀嚼機能評価表において術前に食べる ことができた食品に加え，するめ以外の食品が普通に食べ ることができるようになり，咀嚼スコアは術前の 35 (点) から 95 (点) へと増加した。

また術後 36 力月時の咬合接触検査において, 術前と比 較し咬合接触面積は $8.7\left(\mathrm{~mm}^{2}\right)$ から $52.6\left(\mathrm{~mm}^{2}\right)$ へ，咬 合接触数は 25 (number) から 72 (number) へと増加し, バランス評価はRANK E から RANK B となった(図 10).

\section{IV. 考 察}

$1 \mid 1$ 欠損部に対して補綴装置にブリッジを選択したこと で，審美領域における直接支台装置が $3 \mid 3$ のみとなり，I バークラスプを用いたことと，歯冠補綴装置による歯列の 連続性が得られたことで審美障害は大きく改善されたと考

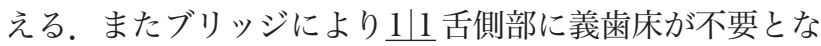
ることで, 舌尖が触れ発現していた感覚障害, および繰り返 し起こっていた同部の義歯の破折が無くなったと考える.

上顎旧義歯の後縁は感覚障害のため大きく削合されてお り，床の縮小に伴い義歯の安定が損なわれ咀嚼障害を呈し ていた。これに対して上顎義歯における大連結子の形態を 感覚障害の発現しない範囲において可及的に広く設定し， 支台歯には連結固定を行った上でレストシート，ラベット
を付与したことで義歯の支持機能が向上し，またミリング テクニックを用いたことで把持機能が向上したと考える. これにより機能時の義歯の動摇を最小限に抑えられた結 果, 疼痛無く, 咀嚼機能の回復および残存歯の保全を行う ことができたと考える.

\section{V. 結 論}

複数の障害の要因に対して, 義歯およびブリッジの選択・ 維持装置・連結子・歯冠補綴装置を含めた補綴装置の設計 を考慮することで，障害の要因を取り除くことができたた め, 非常に良好な結果が得られた。

$$
\text { 文献 }
$$

1）社団法人日本補経歯科学会 医療委員会診療ガイドライン 作成部会. 歯の欠損の補経歯科診療ガイドライン 2008. 補 綴誌 2009；1：E83-E202.

2）宮地建夫．欠損歯列の臨床評価と処置方針．東京：医歯薬 出版；1998，38-44.

3）佐藤裕二，石田栄作，皆木省吾，赤川安正，津留宏道．総 義歯装着者の食品摂取状況。補綴誌 $1988 ； 32: 774-779$.

4）社団法人日本補経歯科学会医療問題検討委員会. 症型分類 特に歯質, 部分歯列欠損, 無歯顎について。補経誌 2005; $49: 373-411$.

5）虫本栄子, 小野田利枝, 河上雄之介, 田中久敏。大連結子 のデザインの違いが口腔感覚に及ぼす影響に関する脳波学 的検討. 補綴誌 $2005 ; 49: 478-487$.

6) 大久保力廣．歯に最大限の支持と把持を求める。 日補綴会 誌 $2016 ; 8: 39-44$.

7）永田省藏。可撤性支台装置は何が良いのか？日補綴会誌 $2017 ; 9: 199-204$.

8）若林則幸，上野剛史，笛木賢治。大連結子と小連結子の設計 に連結効果以上の機能を期待する。日補綴会誌 $2017 ; 9$ : 205-210.

9）大川周治。パーシャルデンチャーによる咬頭嵌合位と中心 咬合位の一致。日補綴会誌 $2016 ; 8: 33-38$.

10）佐藤雅之，谷田部 優，藍 稔，若林則幸，中村和夫。新 たに装着した部分床義歯に対する患者の満足度の評価。補 綴誌 $1999 ; 43: 871-876$.

著者連絡先 : 堤 一輝

干 238-8580 神奈川県横須賀市稲岡町 82 番地 神奈川歯科大学全身管理医歯学講座顎咬合機能 回復補経医学分野

Tel: 046-822-8751

E-mail: tsutsumi@kdu.ac.jp 